To cite this article: Karabulut D, Karabulut U, Yıldız CE, Oflar E, Bilge M, Erdal GS, Caglar N, Akturk IF, Bingol G, Isıksacan N. The relationship between red blood cell distribution width and isolated coronary ectasia.Turk J Clin Lab 2021; 4: 385-390.

\title{
The relationship between red blood cell distribution width and isolated coronary ectasia
}

\section{Alyuvar dağılım genişliği ile izole koroner ektazi arasındaki ilişki}

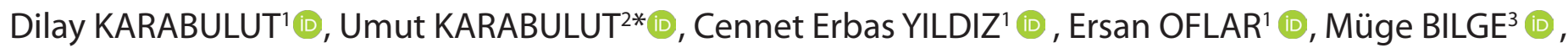

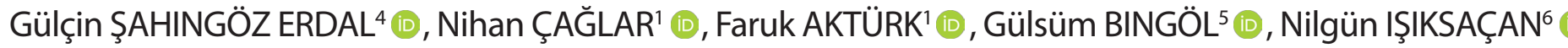

'Bakırkoy Dr. Sadi Konuk Training and Research Hospital, Department of Cardiology, İstanbul, Turkey ${ }^{2}$ Acıbadem International Hospital, Department of Cardiology, Istanbul, Turkey

${ }^{3}$ University of HealthSciences, Prof.Dr.CemilTascioglu CityHospital,DepartmentofInternal Medicine,Istanbul,Turkey ${ }^{4}$ Bakırkoy Dr. Sadi Konuk Training and Research Hospital, Department of Medical Oncology, Istanbul, Turkey ${ }^{5}$ İstanbul Memorial Bahçelievler Hospital,Department of Cardiology,Istanbul,Turkey ${ }^{6}$ Bakırkoy Dr. Sadi Konuk Training and Research Hospital,Department of Biochemistry, Istanbul, Turkey

\begin{abstract}
Aim: Isolated coronary artery ectasia (CAE) is an abnormal dilatation of the coronary artery which cause ischemia. RDW has been investigated in several cardiovascular disorders and has also been recently proposed as a predictive biomarker of adverse outcomes in patients with these conditions. We hypothesized that increased RDW would be associated with isolated CAE because both are associated with inflammation.

Material and Methods: We studied 140 subjects, including 69 patients with isolated CAE, 71 patients with angiographically normal controls. Baseline clinical characteristics and laboratory findings, including RDW, were compared among two groups.

Results: The level of RDW was significantly higher in isolated CAE than normal controls $(14,36 \pm 1,61 \mathrm{vs} 13,59 \pm 1.57$, $\mathrm{p}=0.005)$. In addition, the levels of glomerular filtration rate and creatinin, high density lipoprotein and low density lipoprotein were significantly lower in isolated CAE than normal controls $(76,43 \pm 19,64$ vs $100,36 \pm 18,3$ and $0,9 \pm 0,28$ vs $0,74 \pm 0,25,43,39 \pm 10,09$ vs $48,4 \pm 13,67,121,36 \pm 32,05$ vs $143,70 \pm 55,33 p=0,001, p=0,001, p=0,01, p=0,004$ respectively). In a ROC curve analysis, a RDW value of 13,5 was identified as an effective cut off point for the discrimination of the presence or absence of isolated CAE (Area Under curve [AUC]: 0.71, CI 95\%, 0.62-0.80, p<0,001).
\end{abstract}

Conclusion: Our data suggested that RDW may be a useful marker to predict CAE

Keywords: Red cell; distribution width; coronary ectasia.

Corresponding Author*: Umut Karabulut, Acıbadem International Hospital, Department of Cardiology, Istanbul/ TURKEY

E-mail: umkarabulut@gmail.com

ORCID: 0000-0002-3947-9173

Recevied: 12.10.2021 accepted: 15.11.2021

Doi: $10.18663 /$ tjcl.1008342 


\section{Öz}

Amaç: İzole koroner arter ektazisi (CAE), koroner arterin anormal genişlemesidir ve iskemiye neden olabilir. RDW, çeşitli kardiyovasküler bozukluklarda araştırılmıştırve yakın zamanda,hastalarda olumsuz sonuçların öngörücü bir biyobelirteçi olabileceği öne sürülmüştür. Artmış RDW'nin,her ikisi de inflamasyonla ilişkili olduğu için, izole CAE ile de ilişkili olacağını varsaydık.

Gereç ve Yöntemler: İzole CAE'li 69 hasta ve anjiyografik olarak normal 71 hasta olmak üzere 140 denek üzerinde çalışıldı. Temel klinik özellikler ve RDW dahil laboratuvar bulguları iki grup arasında karşılaştırıldı.

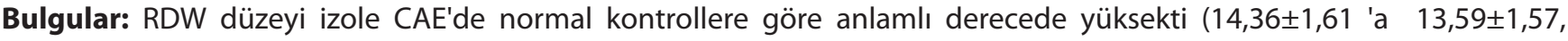
$p=0,005)$. Ek olarak, izole CAE'de glomerüler filtrasyon hızı ve kreatinin, yüksek yoğunluklu lipoprotein ve düşük yoğunluklu

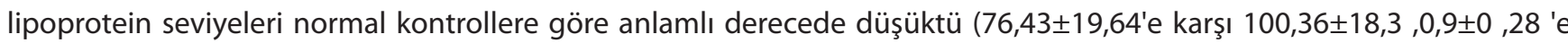

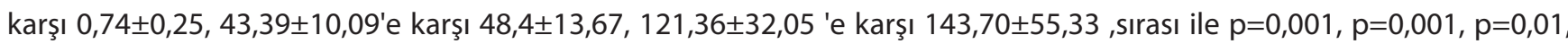
$\mathrm{p}=0,004)$. ROC eğrisi analizinde, 13,5'lik bir RDW değeri, izole CAE'nin varlığının veya yokluğunun ayrımında etkili bir kesme noktası olarak tanımlandı ([AUC]: 0,71, Cl \%95, 0,62-0,80, p<0,001).

Sonuç: Verilerimiz, RDW'nin izole CAE varlığını saptamak için yararlı bir belirteç olabileceğini göstermiştir.

Anahtar Kelimeler: Alyuvar; dağılım genişliği; koroner ektazi.

\section{Introduction}

Coronary artery ectasia (CAE) is defined as the abnormal dilatation of the epicardial coronary artery exceeding 1.5 times the normal adjacent coronary artery segments (1). It is a welldefined, pathological, non-obstructive finding of coronary arteries diagnosed by coronary angiography (2). Although previous studies have demonstrated that CAE could predispose to adverse coronary events like vasospasm, thrombosis, dissection, and even myocardial infarction $(3,4)$, the underlying mechanisms responsible for this vascular disease are unknown. In the light of the previous reports, it may be suggested that there may be more than one mechanism. There is gaining interest in addition to other pathophysiological and molecular mechanisms, inflammation and plays a key role during the aneurysmal dilatation of coronary vessels (5).

The red blood cell distribution width (RDW), part of a routine complete blood count, is a simple and inexpensive parameter, which reflects the degree of heterogeneity of erythrocyte volume (conventionally known as anisocytosis), and is traditionally used in laboratory hematology for differential diagnosis of anemias (6). RDW has been investigated in several cardiovascular disorders and has also been recently proposed as a predictive biomarker of adverse outcomes in patients with these conditions. Recently, many previous studies have linked the baseline RDW to predicting the presence and outcomes of several cardiovascular diseases, including acute coronary syndrome, heart failure, peripheral vascular disease (PVD), stroke, cardiac syndrome $X$, even slow coronary flow syndrome $(7,12)$. RDW has been investigated due to its prognostic value in treating cardiovascular events since the tests are simple to perform, inexpensive, and easily accessible. In addition, there are many reports showing an association between RDW and inflammation and neurohormonal and cardiovascular risk factors $(13,14)$.

Given that the mechanism of increased RDW and pathogenesis of CAE are similar, we hereby evaluate the association between RDW levels and the presence of CAE.

\section{Materials and Methods}

\section{Study Population}

In this study, 6550 patients who underwent coronary angiography in our center between January 2016 and December 2020 for various indications were retrospectively evaluated. Sixty-one patients had isolated CAE. The control group consisted of 79 age and gender-matched individuals who were selected consecutively from among catheterized patients during the same study period who had normal coronary angiograms.

Patients with a history or evidence of CAD, malignancy, valvular heart disease, congestive heart failure, inflammatory disease, current use of corticosteroids were excluded from the study. In addition, patients who have had a previous history of anemia, have received last red blood cell transfusion or were on treatment for anemia, such as supplemental iron, folate, or an erythropoiesis-stimulating agent, were not included in this study. Patients with known hematological diseases such as hemolytic anemia, neoplastic metastases to the bone marrow, iron replacement therapy that could increase plasma RDW levels were excluded. The patients' laboratory and clinical characteristics, such as age, sex, diabetes mellitus 
(DM), hypertension (HT), history of PVD, and cerebrovascular disease (CVD), were accessed through medical records.

CAE was defined as coronary arteries with a luminal dilatation of 1.5 fold or more of the adjacent normal coronary segment without significant coronary stenosis in this study, according to previously reported investigations $(15,16)$. If there was no adjacent segment, the mean diameters of the control patients were used for the related segment (15). Patient with CAE but no significant obstructive coronary artery disease (less than $30 \%$ coronary stenosis) was defined as the isolated CAE including localized/ focal or diffuse dilatation of a coronary artery (15). The patients with significantly concomitant CAD (more than $30 \%$ stenosis in any coronary arteries) were excluded. The normal controls were defined as normal coronary angiography.

\section{Laboratory Measurements}

Hemoglobin ( $\mathrm{Hb}), \mathrm{RDW}$, and white blood cell (WBC) count, and other hematological indices were measured as part of the automated complete blood count (CBC) using a Coulter LH 780 Hematology Analyzer (Beckman Coulter Ireland Inc, Mervue, Galway, Ireland).

\section{Coronary Angiography}

Left ventricular and selective coronary angiography for were performed using the standard Judkin's techniques, and the evaluations were analyzed visually by at least two interventional cardiologists. The vessel diameter was calculated quantitatively in case of the presence of conflict about CAE.

\section{Definitions}

Hypertension was defined as a systolic blood pressure of $\geq 140$ $\mathrm{mm} \mathrm{Hg}$ and/or diastolic blood pressure of $\geq 90 \mathrm{~mm} \mathrm{Hg}$ in at least two measurements or use of any antihypertensive drug. Diabetes mellitus was defined as a fasting plasma glucose level of $>126$ or $>200 \mathrm{mg} / \mathrm{dL}$ or usage of any antidiabetic agent.

The protocol was approved by the ethics committee of Bakırköy Dr.Sadi Konuk Training and Research Hospital (App no:2021-1307) and complied with the Declaration of Helsinki (2013).

\section{Statistical analysis}

\section{Results}

Baseline clinical characteristics of the population studied with isolated CAE $(n=61)$ and normal controls $(n=79)$ are presented in Table 1. There were no significant differences among the groups for PVD, CVD, DM. However, compared with the two groups, the patients with isolated CAE were older and were predominantly male. Additionally, the percentage of hypertension was significantly higher in patients with CAE group compared with the control group $(p>0.001)$

\begin{tabular}{|c|c|c|c|}
\hline & Ectasia $(n=61)$ & Normal $(n=79)$ & P values \\
\hline Age, years & $55,28 \pm 10,66$ & $51,18 \pm 8,79$ & 0,03 \\
\hline Female, n (\%) & $17(27,9 \%)$ & $42(53,2 \%)$ & 0,003 \\
\hline PAH & $2(3,3 \%)$ & $2(2,5 \%)$ & 0,803 \\
\hline $\begin{array}{l}\text { Diabetes mellitus } \\
\text { on treatment }\end{array}$ & $16(26,2 \%)$ & $14(17,7 \%)$ & 0,239 \\
\hline $\begin{array}{l}\text { Arterial hyperten- } \\
\text { sion on treatment }\end{array}$ & $41(67,2 \%)$ & $29(30,7 \%)$ & $<0,001$ \\
\hline
\end{tabular}

Laboratory findings from patients with isolated CAE and normal controls are summarized in Table 2. As showed in Table 2 , there were no differences among the groups regarding hemoglobin, hematocrit, lymphocyte and monocyte count, lymphocyte to monocyte ratio, WBC, and platelet levels. However, the level of RDW was significantly higher in isolated CAE than in normal controls $(14,36 \pm 1,61$ vs $13,59 \pm 1.57$, $\mathrm{p}=0.005)$. In addition, the levels of glomerular filtration rate and creatinine, high density lipoprotein cholesterol (HDL-C) and low density lipoprotein cholesterol (LDL-C) were significantly lower in isolated CAE than normal controls $(76,43 \pm 19,64$ vs $100,36 \pm 18,3$ and $0,9 \pm 0,28$ vs $0,74 \pm 0,25,43,39 \pm 10,09$ vs $48,4 \pm 13,67,121,36 \pm 32,05$ vs $143,70 \pm 55,33 p=0,001, p=0,001$, $p=0,01, p=0,004$ respectively).

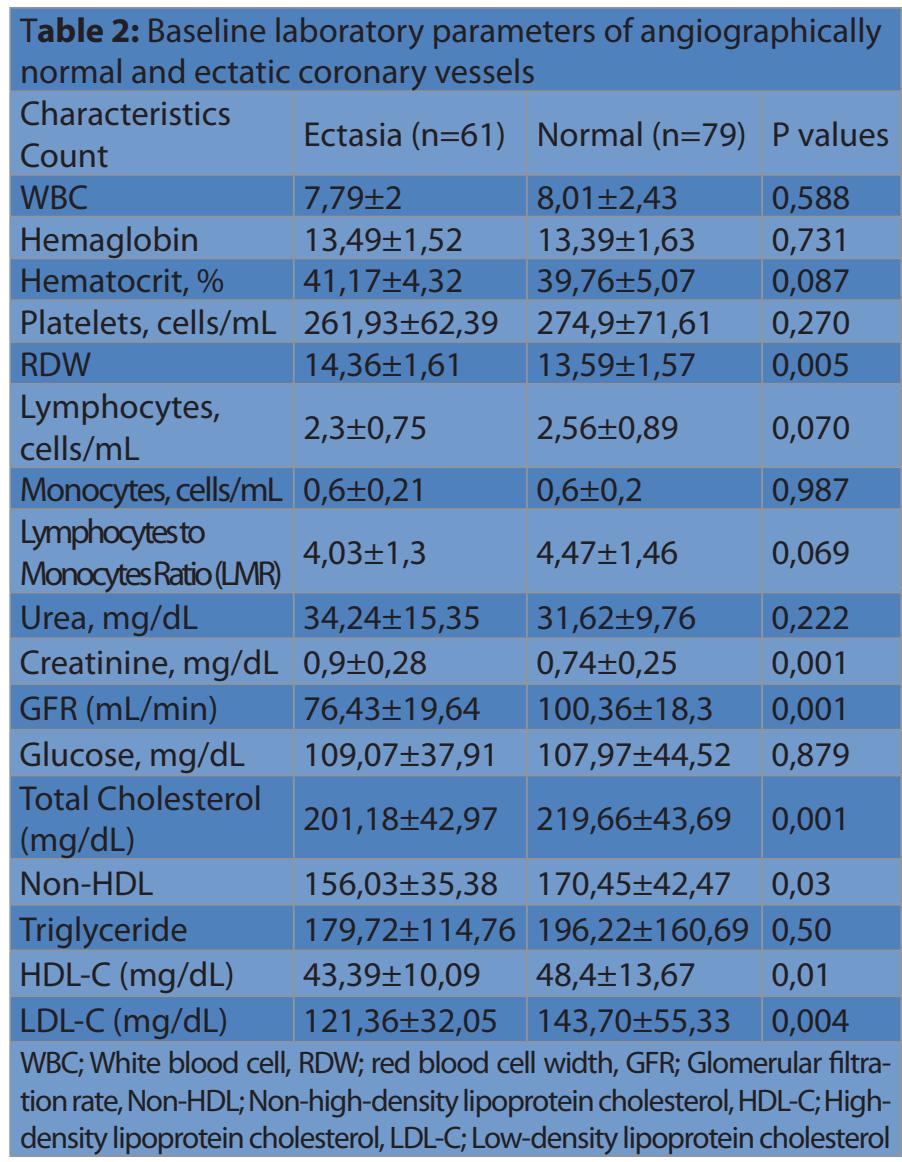


In a ROC curve analysis, the RDW value of 13,5 was identified as an effective cut-off point in the segregation of the presence or absence of isolated CAE (Area Under curve [AUC]: 0.71, CI 95\%, $0.62-0.80, p<0,001)$. A RDW value $\geq$ of 13.5 yielded a sensitivity of $71 \%$, specificity of $67 \%$, a positive predictive value of $60 \%$, and a negative predictive value of $78 \%$ (Figure1).

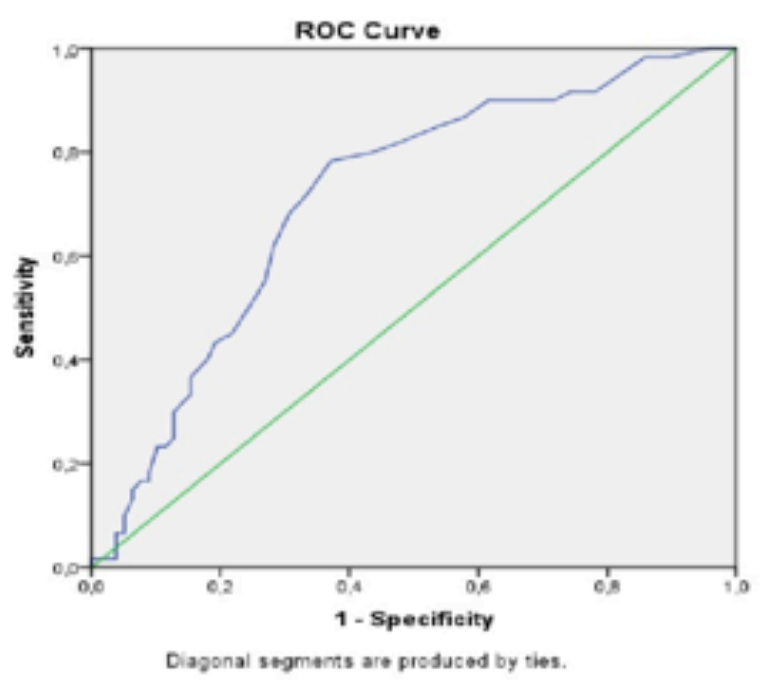

AUC: 0.71, CI 95\%, 0.62-0.80, p<0,001.

Figure.1 ROC curve analysis revealed that the RDW value of 13,5 was identified as an effective cut-off point in the segregation of the presence or absence of isolated CAE (Area Under curve [AUC]: 0.71, Cl 95\%, 0.62$0.80, p<0,001)$ with a sensitivity of $71 \%$ and specificity of $67 \%$

\section{Discussion}

The significant findings of the present study are the RDW levels, and advanced age was significantly higher in patients with isolated CAE than that in angiographically normal controls. This study also showed that isolated CAE was associated with cardiovascular risk factors such as HT.

CAE is an inappropriate dilatation of the coronary artery and might be a variant of the CAD. The CAE can cause angina pectoris and even $\mathrm{MI}$ with vasospasm, dissection, or thrombus in patients without CAD $(3,4)$. In several studies, patients with CAE have been shown to have an increased risk of mortality, equivalent to the patients with CAD (17). Determination of the factors associated with the presence and severity of CAE may help manage these patients. Although the underlying etiology is not precisely known, previous studies reported that inflammation, neurohormonal process, and cardiovascular risk factors were associated with CAE (18-21).
RDW measures the variability in the size of circulating erythrocytes and is a parameter that is routinely reported as part of a complete blood count. Factors contributing to increased erythrocyte size heterogeneity include iron or vitamin B12/folate deficiency (6).

Recently, RDW has been investigated in several cardiovascular diseases and has also been proposed as a marker of adverse outcomes in patients with these conditions $(22,23)$. A study performed by Dogdu et al.in 54 patients with CAE and 40 matched control individuals reported that RDW was higher in the CAE patients than the control subjects (24). We found similar results with this study.

The pathophysiologic mechanisms that the correlation of higher levels of RDW with CAE are mainly unknown. It has been hypothesized that systemic factors, such as inflammation and oxidative stress, might be the potential contributions. Recent data have shown that CAE is associated with inflammatory response presented as elevated inflammatory markers such as C-reactive protein (CRP), interleukin-6, tumor necrosis factor- $a$, matrix metalloproteinases, and WBC counts $(18,19,21)$. Infiltration of the media layer by inflammatory cells in ectasia segments supports these findings (25).

In our study, we did not measure those markers; on the contrary, WBC was lower in the CAE group. Inflammatory cytokines probably suppress the maturation of erythrocytes and induce the release of immature erythrocytes into circulation, which leads to an increased RDW (26).

Oxidative stress is another explanation of this pathophysiology. Oxidative stress decreases the rate of erythroid maturation and erythrocyte lifespan and increases red blood cells' fragility (27).

Furthermore, elevated levels of inflammatory cytokines, neurohormonal markers, and oxidative stress have been shown to cause the formation of ectasia by damaging vessel walls. Also, the relation of the levels of these markers with ectatic vessel diameter has been demonstrated $(25,28,29)$. Additionally, Sağlam et al. showed that CAE is associated with traditional risk factors such as HT, smoking, and hyperlipidemia (30). Similarly, we found the percentage of HT was significantly higher in the CAE group.

In conclusion, in the present study, our data demonstrated that RDW levels were higher in patients with isolated CAE, and suggesting that RDW, an easy, inexpensive, routinely reported test, whose assessment might allow significant diagnostic and prognostic information in patients with cardiovascular disorders may be a useful marker in patients with isolated CAE. 


\section{Limitations of the Study}

Our study had some limitations. First, only $\mathrm{Hb}$ levels were measured in this study, and other factors, including iron, vitamin B12, and folate, were not measured. Second, this was a retrospective study; therefore, we did not analyze longterm events. Third, the evaluation of coronary angiography was performed on visual assessment. The vessel diameter was calculated quantitatively by quantitative coronary angiography in case of conflicts about $\mathrm{CAE}$, and the definition of normal coronary arteries is based on visual assessment. It would be better to examine intravascular techniques such as ultrasound whether the patients with isolated CAE had evidence of atherosclerotic plaque.

Declaration of conflict of interest: The authors declare that they have no known competing financial interests or personal relationships that could have appeared to influence the work reported in this paper.

\section{References}

1. Swaye PS, Fisher LD, Litwin P, et al. Aneurysmal coronary artery disease. Circulation. 1983; 67: 134-8.

2. Pinar Bermudez E, Lopez Palop R, Lozano Martinez-Luengas I, et al. [Coronary ectasia: prevalence, and clinical and angiographic characteristics]. Rev Esp Cardiol. 2003; 56: 473-9.

3. Valente S, Lazzeri C, Giglioli C, et a. Clinical expression of coronary artery ectasia. J Cardiovasc Med (Hagerstown) 2007; 8: 815-20.

4. Giannoglou GD, Antoniadis AP, Chatzizisis YS, Damvopoulou E, Parcharidis GE, Louridas GEet al. Prevalence of ectasia in human coronary arteries in patients in northern Greece referred for coronary angiography. Am J Cardiol 2006; 98: 314-8.

5. Li JJ. Inflammation in coronary artery diseases. Chin Med J (Engl). 2011; 124: 3568-75.

6. Saigo K, Jiang M, Tanaka C, et al. Usefulness of automatic detection of fragmented red cells using a hematology analyzer to diagnose thrombotic microangiopathy. Clin Lab Haematol 2002; 24: 347-51.

7. Tonelli M, Sacks F, Arnold M, et al.Recurrent Events Trial I: Relation Between Red Blood Cell Distribution Width and Cardiovascular Event Rate in People With Coronary Disease. Circulation 2008, 117: $163-8$.

8. Felker GM, Allen LA, Pocock SJ, et al. Investigators C: Red cell distribution width as a novel prognostic marker in heart failure: data from the CHARM Program and the Duke Databank. J Am Coll Cardiol 2007; 50: 40-7.
9. Ye Z, Smith C, Kullo IJ. Usefulness of red cell distribution width to predict mortality in patients with peripheral artery disease. Am J Cardiol 2011; 107: 1241-5.

10. Ani C, Ovbiagele B. Elevated red blood cell distribution width predicts mortality in persons with known stroke. J Neurol Sci 2009; 277: 103-8.

11. Qing $\mathrm{P}$, Luo $\mathrm{SH}$, Guo $\mathrm{YL}$, et al. Evaluation of red blood cell distribution width in patients with cardiac syndrome $X$. Dis Markers 2013; 34: 333-9.

12. Luo SH, Jia YJ, Nie SP, et al. Increased red cell distribution width in patients with slow coronary flow syndrome. Clinics (Sao Paulo) 2013; 68: 732-7.

13. Lippi G, Targher G, Montagnana M, et al. Relation between red blood cell distribution width and inflammatory biomarkers in a large cohort of unselected outpatients. Arch Pathol Lab Med. 2009; 133: 628-2.

14. Lappe JM, Horne BD, Shah SH, et al. Red cell distribution width, C-reactive protein, the complete blood count, and mortality in patients with coronary disease and a normal comparison population. Clin Chim Acta. 2011; 412: 2094-9.

15. Satran A, Bart BA, Henry $C R$, et al. Increased prevalence of coronary artery aneurysms among cocaine users. Circulation 2005; 111: 2424-9.

16. Li JJ, He JG, Nan JL, et al. Is systemic inflammation responsible for coronary artery ectasia? Int J Cardiol 2008; 130: 69-70.

17. Harikrishnan S, Sunder KR, Tharakan J, et al. Coronary artery ectasia: angiographic, clinical profile and follow-up. Indian Heart J. 2000; 52: 547-53.

18. Li JJ,Nie SP,QianXW,et al. Chronic inflammatory status in patients with coronary artery ectasia. Cytokine. 2009; 46: 61-4.

19. Turhan H, Erbay AR, Yasar AS, et al. Comparison of C-reactive protein levels in patients with coronary artery ectasia versus patients with obstructive coronary artery dis- ease. Am J Cardiol. 2004; 94: 1303-6.

20. Finkelstein A, Michowitz $Y$, Abashidze A, et al. Temporal association between circulating proteolytic, inflammatory and neurohormonal markers in patients with coron- ary ectasia. Atherosclerosis. 2005; 179: 353-9.

21. Aydin M, Tekin IO, Dogan SM, et al. The levels of tumor necrosis factor-alpha and interleukin- 6 in patients with isolated coronary artery ectasia. Mediators Inflamm.2009; 2009: 106145. 
22. Mavrogeni SI, Manginas A, Papadakis E, et al. Coronary flow evaluation by TIMI frame count and magnetic resonance flow velocity in patients with coronary artery ectasia. J Cardiovasc Magn Reson. 2005; 7: 545-50.

23. Balin M, Celik A, Kobat MA. The association between soluble lectin-like oxidized low-density lipoprotein receptor-1 levels and patients with isolated coronary artery ectasia. J Thromb Thrombolysis. 2012; 33: 239-45.

24. Dogdu O, Koc F, Kalay N, et al. Assessment of red cell distribution width (RDW) in patients with coronary artery ectasia. Clin App Thromb Hemost. 2012; 18: 211-4.

25. Antoniadis A.P, Chatzizisis Y.S, Giannoglou G.D. Pathogenetic mechanisms of coronary ectasia. Int J Cardiol 2008; 130: 335-43.

26. Pierce CN, Larson DF. Inflammatory cytokine inhibition of erythropoiesis in patients implanted with a mechanical circulatory assist device. Perfusion 2005; 20: 83-90.
27. Marinkovic D, Zhang $X$, Yalcın $S$,et al. Foxo3 is required for the regulation of oxidative stress in erythropoiesis. J Clin Invest. 2007; 117: 2133-44.

28. Kajinami K, Kasashima S, Oda Y, et al.Coronary ectasia in familial hypercholesterolemia: histo- pathologic study regarding matrix metalloproteinases. Mod Pathol. 1999; 12: 1174-80.

29. Sezen $Y$, Bas $M$, Polat $M$, et al. The relationship between oxidative stress and coronary artery ectasia Cardiol J 2010; 17: 488-94.

30. Saglam M, Karakaya O, Barutcu I, et al. Identifying Cardiovascular Risk Factors in a Patient Population With Coronary Artery Ectasia. Angiology, 2007; 58: 698-703. 